\title{
PEMIKIRAN PENDIDIKAN ISLAM PADA MASA UMAYYAH
}

\author{
Yussi Mutia Puspitasari \\ Universitas Islam Negeri Sultan Syarif Kasim Riau \\ E-mail: yussimutiaps@gmail.com \\ Yuliharti \\ Universitas Islam Negeri Sultan Syarif Kasim Riau \\ Yanti \\ Universitas Islam Negeri Sultan Syarif Kasim Riau
}

\begin{abstract}
Abstrak
Islam sebagai agama universal memberikan pedoman hidup bagi manusia menuju kehidupan yang bahagia, yang pencapaiannya sangat bergantung pada pendidikan, oleh karena itu Islam dan pendidikan mempunyai hubungan yang sangat erat. Dinasti Umayyah sebagai dinasti pertama sebagai abad ekspansi yang menyangkut kekaisaran multikultural yang sadar akan kebutuhan pendidikan. Tujuan kajian ini dilakukan untuk menginvestigasi karakteristik pemikiran pendidikan Islam pada masa Umayyah. Metode kajian yang digunakan yaitu kajian literatur dengan cara mengumpulkan berbagai informasi yang berkaitan dengan karakteristik pemikiran pendidikan Islam pada masa Umayyah. Berdasarkan penelusuran terkait pemikiran pendidikan Islam pada masa Umayyah, ditemukan bahwa terdapat beberapa karakteristik pemikiran pendidikan Islam di masa Umayyah seperti bersifat Arab, menjunjung tinggi nilai keislaman dan sebagainya yang berasal dari pemikiran dan pendapat para ahli juga penulis. Akhirnya dengan bercermin dari proses dan dinamika pertumbuhan dan perkembangan pendidikan pada dinasti umayyah ini, berharap dapat bermanfaat dan kian mencerahkan pemikiran pembaca khususnya bagi teoritisi dan praktisi pendidikan.
\end{abstract}

Kata kunci: Karakteristik, Pemikiran, Pendidikan Islam, Masa Umayyah

\begin{abstract}
Islam as a universal religion provides life guidelines for humans towards a happy life, whose achievement is very dependent on education, therefore Islam and education have a very close relationship. The Umayyah dynasty as the first dynasty as a century of expansion involving a multicultural empire that was aware of the need for education. The purpose of this study was to investigate the characteristics of Islamic education thought during the Umayyah period. The study method used is a literature review by collecting various information related to the characteristics of Islamic education thought during the Umayyah period. Based on a search related to Islamic education thought during the Umayyah period, it was found that there were several characteristics of Islamic education thought in the Umayyah period such as being Arabic, upholding Islamic values and so on that came from the thoughts and opinions of experts as well as writers. Finally, by reflecting on the process and dynamics of the growth and development of education in the Umayyah dynasty, it is hoped that it can be useful and further enlighten the minds of readers, especially for educational theorists and practitioners.
\end{abstract}

Keywords: Characteristics, Thought, Islamic Education, Umayyah Period 


\section{Pendahuluan}

Perkembangan pendidikan Islam dewasa ini sangat erat kaitannya dengan kejadian-kejadian yang dicatat dalam sejarah. Dalam perkembangannya pendidikan terus melihat dan belajar dari perjalanan para pendahulu yang ingin membangun pendidikan Islam menjadi ilmu yang dapat diterima secara universal.

Pemikir Islam menjelaskan bahwa peran pemikir Islam terdahulu juga sangat besar pengaruhnya dalam perkembangan pendidikan Islam, melalui pertikaian politik, sosial dan ekonomi, pendidikan Islam tetap dapat sampai pada generasi-generasi berikutnya. Dalam pembahasan pemikiran pendidikan Islam, terlebih dahulu kita harus mengerti batas dan pokok bahasan yang ada dalam materi, sehingga pembahasan menjadi relevan. Pemikiran pendidikan Islam merupakan hasil olah pikir para pemikir intelektualisme, filosof, dan cendikiawan yang menganggap pentingnya pendidikan Islam dalam menyebarkan agama Islam itu sendiri.

Para pemikir Islam menganggap perlu untuk mengembangkan ilmu pengetahuan, terutama dalam pendidikan Islam, dan hal ini menjadi latar belakang para pemikir membahas kaitan sejarah dan hubungannya dengan pendidikan. Pada pembahasan sebelumnya kita telah mendengar bagaimana perkembangan pendidikan Islam sejak masa awal datangnya Islam, sejak dari Makkah hingga Madinah yang dibawa oleh Nabi Muhammad hingga para khulafaurrasyidin. Penyebaran dan perkembangan pendidikan Islam masa awal ini telah mengorbankan begitu banyak hal, dari harta hingga nyawa. Meski dalam situasi yang paling berbahaya sekalipun, para pendahulu tetap teguh dalam menyebarkan dan menanamkan pendidikan Islam dalam setiap aspek kehidupan mereka. Selanjutnya dalam makalah ini akan membahas sejarah pemikiran pendidikan Islam masa Dinasti Umayyah. Dalam pembahasan ini akan dipaparkan bentuk dan spesifikasi pendidikan yang ada pada masa Dinasti Umayyah.

Kajian terdahulu mengenai perkembangan pendidikan masa dinasti Umayyah yang dilakukan oleh Muchlis pada tahun 2020 yang menjelaskan mengenai sistem pemerintahan Bani Umayyah yang mengalami banyak perubahan seperti dilakukannya musyawarah untuk memilih khalifah dengan sistem monarki, pembentukan dewandewan, penetapan pajak dan kharaj, sistem pemerintahan provinsial dan kemajuan di bidang militer. Adapun mengenai pemikiran pendidikan Islam pada masa dinasti Umayyah tidak dijelaskan secara rinci dalam kajian ini. Oleh karena itu, penulis ingin menjabarkan sedetail mungkin terkait informasi mengenai pemikiran pendidikan Islam pada masa dinasti Umayyah ini.

Tujuan kajian ini dilakukan untuk mengeksplorasi aspek pemikiran pendidikan yang telah membangun peradaban di Era Umayyah. Hasil yang ingin dicapai oleh penulis mengenai kajian ini tentunya bisa menjadi salah satu acuan untuk mencari informasi terkait dengan apa-apa saja karakteristik pemikiran pendidikan Islam pada masa Umayyah. 


\section{Metode}

Metode kajian yang digunakan yaitu kajian literatur dengan cara mengumpulkan berbagai informasi yang berkaitan dengan karakteristik pemikiran pendidikan Islam pada masa Umayyah.

\section{Hasil dan Pembahasan}

Muawiyah bin Abi Sofyan merupakan pendiri dan tokoh utama dinasti Bani Umayyah. Nama ini diambil nama nenek mereka yang bernama Umayyah bin Abdi Manaf. Dinasti Bani Umayyah berkuasa kurang lebih 91 tahun sejak $41 \mathrm{H}$ hingga $132 \mathrm{H}$, dengan 14 orang khalifah yang memimpin kekuasaan. Bani Umayyah melakukan pembangunan dan perluasan wilayah yang terbentang dari Andalusia (Spanyol) hingga India. Masyarakat muslim tumbuh menjadi masyarakat multicultural, berbagai macam etnis dan bangsa telah menjadi pemeluk. Di tengah pertumbuhan, kebutuhan masyarakat kepada pendidikan semakin besar. Dengan memeluk erat nilai-nilai dasar ajaran Islam, dinasti Umayyah membangun dan mengembangkan pendidikan.

Pergolakan politik dan gerakan-gerakan militer pada masa pemerintahan dinasti Umayyah, baik dalam usaha perluasan wilayah Islam maupun dalam menghadapi pemberontakan, menghasilkan pertumbuhan dan perkembangan dalam bidang alam pikiran dan pendidikan. Pandangan hidup umat Islam pada awalnya adalah sama, bersatu dalam Islam, begitu pula dalam pemahaman kepada penafsiran Alquran. ${ }^{1}$ Tidak ditemukan perbedaan pendapat dalam melaksanakan ibadah dan muamalat yang telah

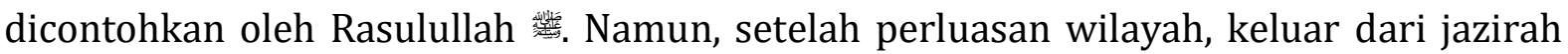
Arab, diikuti dengan budaya yang dikenalkan oleh wilayah yang baru, menjadikan peradaban baru bagi umat Islam. Persinggungan budaya ini menjadikan adanya perbedaan dalam memberikan pendapat mengenai tafsiran Alquran dan sunnah yang telah diajarkan oleh Rasulullah Pandangan hidup umat Islam menjadi terwarnai dengan masuknya budaya, etnis dan bangsa baru dalam segala aspek kehidupan. ${ }^{2}$

\subsection{Umayyah bagian Barat dan Timur}

Kepemimpinan pada masa Muawiyah, peta Islam melebar ke Timur sampai Kabul, Kandahar, Ghazni, Balakh, bahkan sampai kota Bukhara. Selain itu, Kota Samarkand dan Tirmiz menjadi wilayah kekuasaannya, bahkan sampai ke tepi sungai Sind (Shinhu/Indus). Akan tetapi, wilayah Sind secara formal dan permanen menjadi wilayah kekuasaan Islam (Umayyah, saat Muhammad ibn Qasim di bawah instruksi Gubernur Jenderal, Hajjaj ibn Yusuf) pada masa Khalifah al-Walid ibn Abd al-Malik pada 705-715 M.

Pada permulaan masa pemerintahan Yazid, pimpinan kembali diserahkan kepada 'Uqbah ibnu Nafi', sedang Abdul Muhajir jadi pembantunya. Kedua pahlawan besar ini telah berhasil untuk maju terus dalam penaklukan mereka, hingga sampailah

\footnotetext{
${ }^{1}$ Hasan Langgulung, Asas-Asas Pendidikan, (Jakarta, Pustaka al-Husana, 1988)

${ }^{2}$ H. Soekarno dan Ahmad Supardi, Sejarah Dan Filsafat Pendidikan Islam, (Bandung, Angkasa),1983, cet. Ke-2, hlm. 73
} 
mereka ke pantai Lautan Atlantik. 'Uqbah ibnu Nafi' bahkan menaklukkan Chartage (Kartagona), ibu kota Bizantium di Ifriqiyah dan mendirikan masjid bersejarah, Qayrawan dengan membangun pusat kegiatan militer di Kota Qayrawan.

Ekspansi ke Barat secara besar-besaran dilanjutkan di zaman al-Walid ibn Abdul Malik. Masa pemerintahan al-Walid adalah masa ketenteraman, kemakmuran dan ketertiban. Umat Islam merasa hidup bahagia. Pada masa pemerintahannya yang berjalan kurang lebih sepuluh tahun, tercatat suatu ekspedisi militer dari Afrika Utara menuju wilayah Barat Daya, benua Eropa, yaitu pada tahun $711 \mathrm{M}$. Setelah Al-Jazair dan Maroko dapat ditundukkan, Tariq bin Ziyad, pemimpin pasukan Islam, dengan pasukannya menyeberangi selat yang memisahkan antara Maroko dengan benua Eropa, dan mendarat di dengan nama Gibraltar (Jabal Tariq). Tentara Spanyol dapat dikalahkan. Dengan demikian, Spanyol menjadi sasaran ekspansi selanjutnya. Ibu kota Spanyol, Kordova, dengan cepat dapat dikuasai. Menyusul setelah itu kota-kota lain seperti Seville, Elvira, dan Toledo yang dijadikan ibu kota Spanyol yang baru setelah jatuhnya Kordova. Pasukan Islam memperoleh kemenangan dengan mudah karena mendapat dukungan dari rakyat setempat yang sejak penguasa.

Meskipun keberhasilan banyak dicapai dinasti ini, tapi tidak berarti bahwa politik dalam negeri dapat dianggap stabil. Pemberontakan terhadap penguasa mulai terjadi, seperti munculnya gerakan Syi'ah, pemberontakan Abdullah ibn Zubair, gerakan Khawarij, Mu'tazilah, Jabariah, dan Murjiah. Namun, hubungan pemerintah dengan golongan oposisi membaik pada masa pemerintahan khalifah Umar ibn Abd al-Aziz (717-720 M).

\subsection{Karakteristik Pendidikan}

Berikut adalah beberapa karakteristik pendidikan pada masa dinasti Umayyah:

\section{a. Bersifat Arab}

Ciri utama corak pendidikan pada masa dinasti Umayyah adalah bersifat Arab dan Islam Tulen. Artinya yang terlibat dalam dunia pendidikan masih didominasi oleh orang-orang Arab, karena pada saat itu pandangan hidup umat belum bercampur dengan budaya dan peradaban yang baru datang saat perluasan wilayah. Pada masa ini pendidikan berlangsung dengan membentuk halaqah ilmiah di mesjidmesjid.

\section{b. Berpegang Kepada Dasar Agama Islam}

Pada masa dinasti Umayyah penyebaran agama Islam masih berlangsung bersamaan dengan usaha-usaha perluasan wilayah Islam. Pada masa ini, Islam adalah pandangan hidup sebagai agama dan negara. Para khalifah mengutus ulama-ulama terbaik mereka ke berbagai daerah untuk menyebarkan agama Islam. Hal ini sebagai bukti bahwa pada masa dinasti Umayyah penyebaran agama Islam adalah merupakan prioritas utama. ${ }^{3}$

\footnotetext{
${ }^{3}$ Suwito dan Fauzan, Sejarah Sosial Pendidikan Islam, (Jakarta: Kencana, 2005), hlm. 104
} 


\section{c. Prioritas Kepada Ilmu Naqliyah, Aqliyah, dan Bahasa}

Dinasti Umayyah juga memberikan prioritas kepada ilmu naqliyah yang meliputi ilmu-ilmu yang mendalami Alquran, seperti membaca Alquran, tafsir, hadits, tauhid dan fiqih. Belajar dan memahami Alquran juga tidak lepas dari ilmu bahasa dalam Alquran, yaitu bahasa Arab, ilmu yang mendalami bahasa Arab seperti nahwu dan sastra. Adapun aqliyah meliputi filsafat, kedokteran, ilmu kimia dan astronomi, aspek pendidikan Islam ini sejalan dengan karakteristik pertama yang bertujuan untuk memperkuat dasar-dasar agama. Hal ini terbukti ketika pada masa pemerintahan Umar bin abd Aziz pernah mengutus 10 orang ahli fikih ke Afrika utara untuk mengajarkan anak-anak disana.

\section{d. Memberikan Perhatian Kepada Tulisan Sebagai Media Komunikasi}

Pada masa dinasti Umayyah tugas penulisan semakin banyak dan terbagi ke dalam 5 poin penting, yaitu: penulis surat-surat, penulis harta, penulis tentara, penulis polosi dan penulis hakim. Penulisan bahasa Arab menjadi penting ketika setiap wilayah perluasan mengalami arabisasi. ${ }^{4}$ Bahasa Arab dijadikan bahasa komunikasi baik secara lisan maupun tulisan di seluruh wilayah Islam.

\section{e. Memberikan Peluang Pada Bahasa Asing}

Dengan meluasnya wilayah kekuasaan pemerintahan Islam, mempelajari bahasa asing dianggap perlu sebagai akibat dari interaksi negara Islam dengan negera lain. Perluasan wilayah yang dilakukan dinasti Umayyah menjadikan pelajaran bahasa asing menjadi penting agar terwujud Islam yang rahmatan lil'alamin. Pelajaran bahasa asing kemudian memudahkan para ulama dalam menyampaikan ajaran dan nilai-nilai Islam. ${ }^{5} \mathrm{Hal}$ ini terbukti dengan semakin meluasnya kawasan Islam di semenanjung Arab, sehubungan degan hal ini nabi Muhammad juga pernah bersabda "barang siapa yang mempelajari bahasa suatu kaum, niscaya ia akan selamat dari kejahatannya". Keperluan ini semakin dirasakan penting karena pada masa pemerintahan Dinasti Umayyah kawasan Islam semakin meluas sampai ke Afrika dan Cina serta negeri-negeri lainnya yang berbeda dengan Bahasa Arab. Dengan demikian pengajaran bahasa diperketat, hal ini untuk menunjukan bahwa Islam merupakan agama universal.

\section{f. Menggunakan Masjid}

Pada masa dinasti Umayyah, pendirian masjid banyak dilakukan pada wilayah yang baru memeluk ajaran Islam. Fungsi masjid pada masa Umayyah masih sama dengan fungsi masjid pada masa Rasulullah dan khulafaurrrasyidin. Masjid selain berfungsi sebagai tempat beribadah, masjid juga berfungsi sebagai pusat aktivitas ilmiah, syair, sejarah bangsa-bangsa terdahulu, perdebatan serta

\footnotetext{
${ }^{4}$ Samsul Nizar (ed), Sejarah Pendidikan Islam: Menelusurti Jejak Era Rasullah Sampai Indonesia ,(Jakarta: Kencana, 2007), cet- 1, h. 62

${ }^{5}$ Zuhairini, dkk, Sejarah Pendidikan Islam, (Jakarta: Bumi Aksara, 2004), cet ke-7, hlm. 96
} 
kegiatan lainnya. Masjid merupakan tumpuan utama para khalifah dinasti Umayyah pada masa itu. ${ }^{6}$

Dari karakteristik pendidikan yang ada pada masa dinasti Umayyah dapat kita lihat bahwa pemerintahan dinasti Umayyah memberikan perhatian yang sangat besar terhadap keotentikan pendidikan Islam. Pendidikan Islam pada masa pemerintahan Umayyah sangat memperhatikan kemurnian ajaran dan nilai-nilai Islam yang murni diajarkan dan dicontohkan oleh Rasulullah tanpa adanya pencampuran dengan budaya luar dan perbedaan-perbedaan pandangan dalam masalah ibadah dan muamalat. ${ }^{7}$

\subsection{Perkembangan Pendidikan}

Pada masa Dinasti Umayyah pola pendidikannya bersifat desentralisasi dan belum memiliki tingkatan dan standar umum. Kajian pendidikan pada masa itu berpusat di 'Damaskus, Kufah, Mekah, Madinah, Mesir, Kardoba dan beberapa kota lainnya, seperti Basyarah, Kuffah (Irak) Damsyik dan Palestina (Syam), dan Fistat (Mesir)'. Diantara ilmu-imu yang dikembangkan yaitu, Kedokteran, Filsafat, Astronomi, Ilmu Pasti, Sastra, Seni Bagunanan, Seni rupa, maupun Seni suara. Dengan demikian pendidikan tidak hanya berpusat di Madinah seperi pada zaman Nabi dan Khulafaur Rasyidin melainkan ilmu itu telah mengalami ekspansi seiring dengan ekspansi teritorial. ${ }^{8}$ Lebih lanjut pada periode Dinasti Umayyah terdapat beberapa jenis pendidikan, yaitu;

1. Pendidikan khusus yaitu pendidikan yang diselenggarakan dan diperuntukan bagi anak-anak khalifah dan anak-anak para pembesarnya, Tempat Proses pembelajaran berada dalam lingkungan istana, Materi yang diajarkan diarahkan untuk kecakapan memegang kendali pemerintahan atau hal-hal yang ada sangkut pautnya dengan dengan keperluan dan kebutuhan pemerintahan, sehingga dalam penentuan dan penetapan kurikulumnya bukan hanya oleh guru melainkan orang tua pun turun menentukannya. Adapun Materi yang diberikan yaitu materi membaca dan menulis alQuran, al-Hadits, bahasa arab dan syair-syair yang baik, sejarah bangsa Arab dan peperangannya, adab kesopanan, pelajaran-pelajaran keterampilan, seperti menunggang kuda, belajar kepemimpinan berperang. Pendidik atau guru-gurunya dipilih langsung oleh khalifah dengan mendapat jaminan hidup yang lebih baik. Peserta didik atau Anak-anak khalifah dan anak-anak pembesar.

2. Pendidikan yang di peruntukan bagi rakyat biasa. Proses pendidikan ini merupakan kelanjutan dari pendidikan yang telah diterapkan dan dilaksanakan sejak zaman Nabi Muhammad masih hidup. Sehingga kelancaran proses pendidikan ini ditanggungjawabi oleh para ulama, merekalah yang memikul tugas mengajar dan memberikan bimbingan serta pimpinan kepada rakyat. Mereka bekerja atas dasar

\footnotetext{
${ }^{6}$ Mahmud Yunus, Sejarah Pendidikan Islam, (Jakarta: Hidakarya Agung, 1992), hlm. 33

${ }^{7}$ Musyrifah Sunanto, Sejarah Islam Klasik Perkembangan Ilmu Pengetahuan Islam, (Jakarta: Kencana, 2004), hlm. 41-42

${ }^{8}$ Al-Ghajali, Dalam ihya ulumuddin (kairo, 1334), jilid. II, mh. 238, yang dikutip oleh Philip K. Hitti, history, h.345
} 
kesadaran moral serta tanggung jawab agama bukan dasar pengangkatan dan penunjukan pemerintah, sehingga mereka tidak memperoleh jaminan hidup (gaji) dari pemerintah. ${ }^{9}$

Jaminan hidup mereka tanggungjawabi sendiri dengan pekerjaan lain diluar waktu mengajar, atau ada juga yang menerima sumbangan dari murid-muridnya. Adapun ilmu yang diajarkan bukan hanya bidang agama saja, melainkan juga ilmu-ilmu umum. Termasuk didalamnya budaya, peradaban dan sastra Yunani yang masuk pada saat perluasan wilayah dilakukan. Meskipun pemerintahan dinasti Umayyah memberikan kesempatan kepada bidang ilmu umum untuk diajarkan didalam pendidikannya, pada masa itu bidang ilmu didominasi dengan ilmu agama, masih sangat jelas bahwa dinasti Umayyah sangat menganggap perlu untuk menanamkan kemurnian ajaran-ajaran Islam.

\section{Majlis Sastra}

Kemudian ada majlis sastra, majlis ini guna untuk membahas persoalan hukum agama dan berdiskusi mengenai masalah-masalah yang memerlukan pemecahan dan penyelesaian. Saat itu Khalifah Muawiyah sangat tertarik dengan sejarah, yang mana sejarah sangat berguna untuk tugas dan jabatannya dalam usahanya untuk mengendalikan pemerintahan. Khalifah Muawiyah dapat mengambil contoh dan teladan untuk kehidupan dan menentukan sikap untuk masa yang akan datang. Berbeda dengan anak-anaknya, mereka lebih cenderung tertarik dan mencintai syair. ${ }^{10}$

\section{Perpustakaan}

Pada dinasti Umayyah, perhatian terhadap pembinaan dan pengembangan perpustakaan mengalami peningkatan. Perpustakaan pada masa dinasti Umayyah turut maju dan berkembang. Selain fungsinya sebagai tempat untuk menyimpan dan memelihara buku, pada masa dinasti Umayyah perpustakaan juga difungsikan untuk melakukan kegiatan belajar mengajar, pertumbuhan dan perkembangan ilmu pengetahuan serta kegiatan penelitian dan penulisan karya ilmiyah.

\section{Al-Bimaristan}

Cucu Muawiyah, Khalid bin Yazid, sangat tertarik pada ilmu kimia dan kedokteran. Melalui wewenang yang dimilikinya, ia menyediakan sejumlah dana dan memerintahkan para sarjana yang ada di Mesir untuk menerjemahkan bukubuku kimia dan kedokteran ke dalam bahasa Arab, terutama membangun alBimaristan sebagai tempat belajar, magang dan penelitian bagi calon dokter. Selanjutnya, peran yang paling penting terhadap keberlangsungan pendidikan ditempati oleh para pendidik. Pemerintah Umayyah memberikan pendidik terbaik pada tiap-tiap lembaga

\footnotetext{
${ }^{9}$ Samul Munir Amin, Sejarah Peradaban Islam (Jakarta: Amzah, 2009) h.137

${ }^{10}$ Siti Maryam, Sejarah Peradaban Islam Dari Masa Klasik Hingga Kontemporer, (Yogyakarta, LESPI dan jurusan SPI Sunan Kalijogo, 2003), hlm.114-115
} 
yang ada pada masa itu. ${ }^{11}$ Termasuk memberikan sarana dan prasarana agar pendidikan dapat berlangsung dengan meminimalisir segala hambatan. Termasuk di dalamnya dana yang dibutuhkan bagi perkembangan dan tumbuh pendidikan

\subsection{Kemunduran dan Runtuhnya Dinasti Umayyah}

Dinasti Umayyah mengalami kemajuan yang pesat hanya pada dasawarsa pertama kekuasaannya, sedangkan pada tahun berikutnya sudah mengalami kemunduran. Kemajuan yang terjadi pasa masa pemerintahan Muawiyah sampai kepada Hisyam. Adapun beberapa faktor penyebab kemunduran dinasti umayyah adalah:

1. Sistem pergantian khalifah melalui garis keturunan. Pengaturannya tidak jelas sehingga menyebabkan persaingan yang tidak sehat di lingkungan keluarga kerajaan

2. Adanya gerakan oposisi dari pendukung Ali dan Khawarij baik yang dilakukan secara terbuka maupun secara tertutup. Hal ini banyak menyedot perhatian pemerintah ketika itu

3. Timbulnya permasalahan sosial yang menyebabkan orang non Arab dan suku Arabia Utara sehingga Dinasti Umayyah kesulitan untuk menggalang persatuan dan kesatuan

4. Sikap hidup mewah di kalangan keluarga istana dan perhatian terhadap masalah keagamaan sudah berkurang

5. Adanya kekuatan baru yang digalang oleh keturunan al Abbas ibn Abd al Muthalib sehingga menyebabkan keruntuhan kekuasaan Dinasti Umayyah. Gerakan ini didukung penuh Bani Hasyim dan golongan Syiah serta kaum Mawali yang di nomor duakan ketika pemerintahan Bani Umayyah. Dengan demikian dapat menjadi pengalaman bagi setiap pemerintahan yang tidak baik. $^{12}$

\section{Simpulan}

Pemerintahan dinasti Umayyah mengutamakan dasar-dasar agama Islam dalam melaksanakan pendidikan. Setiap bidang ilmu selalu dilandaskan kepada ajaran-ajaran dan nilai Islam. Maka dinasti Umayyah masih menjalankan pendidikan yang masih tradisionalis, bentuk pendidikan yang masih sama dengan pendidikan yang berlangsung pada masa Rasulullah dan khulafaurrasyidin. Hanya saja pada masa dinasti Umayyah pendidikan berlangsung lebih meluas sejalan dengan perluasan wilayah Islam yang dilakukan para khalifah pada masa itu.

Meskipun pendidikan yang berlangsung pada masa dinasti Umayyah merupakan terusan dari metode dan jalan pendidikan yang dilaksanakan pada masa Rasulullah dan para khulafaurrasyidin, atau dapat dikatakan oleh para ahli, pendidikan tradisionalisme, namun perluasan wilayah yang dilakukan menjadi dorongan paling kuat untuk

\footnotetext{
${ }^{11}$ Syamsul Ma'arif, Revitalisasi Pendidikan Islam(Jakarta, Graham Ilmu, 2008), hlm. 13

${ }^{12}$ Anwar, Saepul, “Pendidikan Islam Masa Dinasti Umayah”, Jurnal Tarbiya, Vol. 1 No. 1, 2015
} 
mengembangkan pendidikan menjadi lebih luas. Khalifah Muawiyah, sebagai pemimpin pemerintahan tertinggi pada masa itu, melihat pentingnya menanamkan dasar-dasar agama pada tiap bidang-bidang ilmu. Masuknya budaya baru yang masuk dengan perluasan wilayah, terus disaring, hal ini guna menghindarkan pendidikan agama Islam dari hal-hal yang dapat menyesatkan Islam.

Meskipun secara politik pada masa dinasti ini dipenuhi dengan retorika dan problematika di kalangan umat islam itu sendiri namun tak meyurutkan akan dunia Pendidikan, dimana pada masa dinasti umayyah telah menorehkan benihbenih bagaimana memandang pendidikan sebagai aktivitas yang merdeka 'bebas' dan sarat akan nilai; pengetahuan bebas didapat dari siapa pun dan dari mana pun.

Tentunya jika dikontekstualisasikan pada saat ini, maka dunia pendidikan Islam harus responsif terhadap perkembangan ilmu pengetahuan dan teknologi, dengan tetap meniscayakan nilai-nilai islami yang berperan mencipta suasana kehidupan yang kondusif, humanis, harmonis dan dinamis. Akhirnya dengan bercermin dari proses dan dinamika pertumbuhan dan perkembangan pendidikan pada dinasti umayyah ini, berharap dapat bermanfaat dan kian mencerahkan pemikiran pembaca khususnya bagi teoritisi dan praktisi pendidikan.

\section{REFERENSI}

Al-Ghajali. Dalam ihya ulumuddin. Kairo. 1334, jilid. II, mh. 238, yang dikutip oleh Philip K. Hitti, history, h.345

Anwar. Saepul. Pendidikan Islam Masa Dinasti Umayyah. Jurnal Tarbiya, Vol. 1 No. 1, 2015 Hasan Langgulung, Asas-Asas Pendidikan. Jakarta: Pustaka al-Husana. 1988.

H. Soekarno dan Ahmad Supardi. Sejarah Dan Filsafat Pendidikan Islam. Bandung: Angkasa.1983, cet. Ke-2

Mahmud Yunus. Sejarah Pendidikan Islam. Jakarta: Hidakarya Agung. 1992.

Musyrifah Sunanto. Sejarah Islam Klasik Perkembangan Ilmu Pengetahuan Islam. Jakarta: Kencana. 2004.

Samul Munir Amin. Sejarah Peradaban Islam. Jakarta: Amzah, 2009.

Samsul Nizar. Sejarah Pendidikan Islam. Menelusuri Jejak Era Rasullah Sampai Indonesia . Jakarta: Kencana. 2007. cet-1.

Siti Maryam. Sejarah Peradaban Islam Dari Masa Klasik Hingga Kontemporer. Yogyakarta. 2003

Suwito dan Fauzan. Sejarah Sosial Pendidikan Islam. Jakarta: Kencana. 2005.

Syamsul Ma’arif. Revitalisasi Pendidikan Islam. Jakarta: Graham Ilmu, 2008. 
Zuhairini. Sejarah Pendidikan Islam. Jakarta: Bumi Aksara. 2004, cet ke-7 